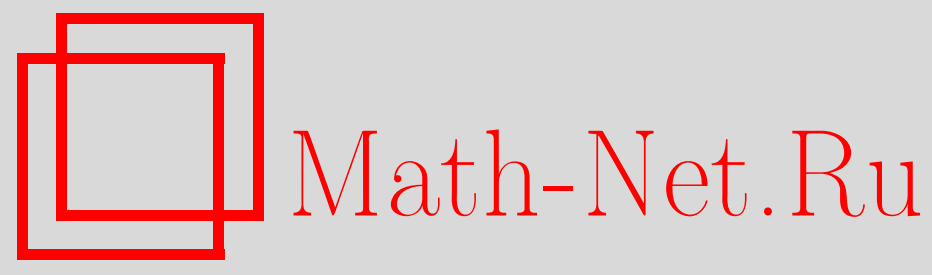

Владимир Николаевич Чубариков (к шестидесятилетию со дня рождения), Дискрет. матем., 2012, том 24, выпуск 2, 3

DOI: https://doi.org/10.4213/dm1179

Использование Общероссийского математического портала Math-Net.Ru подразумевает, что вы прочитали и согласны с пользовательским соглашением http://www.mathnet.ru/rus/agreement

Параметры загрузки:

IP : 18.207 .199 .55

26 апреля 2023 г., 14:36:05 


\section{Владимир Николаевич Чубариков \\ (к шестидесятилетию со дня рождения)}

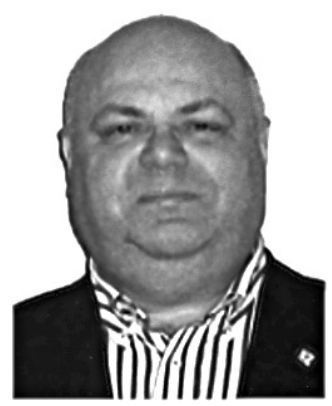

5 сентября 2011 г. исполнилось 60 лет члену Редакционной коллегии журнала «Дискретная математика», доктору физико-математических наук, профессору, декану механико-математического факультета Московского государственного университета имени М. В. Ломоносова Владимиру Николаевичу Чубарикову.

Редакционная коллегия сердечно поздравляет Владимира Николаевича с юбилеем и желает ему доброго здоровья и творческих успехов. 